\title{
The Effect of Informal Cooperative Activity through Online Learning on the Understanding of Physics Concept
}

\author{
Rakhmatul Ummah $^{1}$, Dwi Sulisworo, ${ }^{1,}$, Widodo Raharjo ${ }^{1}$, Guntur Maruto ${ }^{2}$, \\ Nurul Huda Abd. Rahman ${ }^{3}$ \\ ${ }^{1}$ Ahmad Dahlan University, Indonesia \\ ${ }^{2}$ Faculty of Mathematics \& Natural Science, Gadjah Mada University, Indonesia \\ ${ }^{3}$ Faculty of Education \& Teaching, University Pendidikan Sultan Idris, Malaysia
}

Received August 10, 2019; Revised January 20, 2020; Accepted February 20, 2020

Copyright@2020 by authors, all rights reserved. Authors agree that this article remains permanently open access under the terms of the Creative Commons Attribution License 4.0 International License

\begin{abstract}
Educators believe that online learning has many opportunities in providing a conducive learning environment relevant to student characteristics. This study explores the impact of cooperative online learning on student learning outcomes. To reduce the influence of other effected variables, covariates used as control variables were students' interest in learning and numerical abilities. The type of cooperative learning model used in this study was Think Pair Share (TPS) which were integrated into Schoology as a learning management system (LMS). This learning strategy was applied to eleventh-grade students for elasticity topic. The research method was a pretest-posttest controlled group design. Test techniques (10 items of essays) were used to measure learning achievement. Questionnaires with a Likert scale were used to measure learning interest using the ARCS (attention, relevance, and satisfaction) model (34 items). Numerical ability data was collected from secondary data (standard psychological test). The statistical test used in this study was Conbrach's Product Moment from Pearson for item validity, using Cronbach's Alpha for item reliability, ANCOVA to analyze the differences among group means as the effect analysis. The results finding were the group of students taught by the proposed strategy had higher learning outcomes than another group of students. Learning interests and numerical abilities could be used as predictors for improving student learning outcomes. It means that we can apply the online cooperative learning using a specific LMS to promote the increase of student's learning performance.
\end{abstract}

Keywords Online Learning, Cooperative Learning, Learning Management System, Student Achievement, Numerical Ability, Learning Interest.

\section{Introduction}

As the development of technology, all aspects of society's life always connect to from digital influence, including the education field. Mobile learning becomes one of the trends in education that utilizing cellular devices as learning aid or media [1,2]. Using cellular mechanisms enables learning to be more exciting and interactive compared to others, so the term of Learning Management System (LMS) appears.

The more features available on cellular or smartphone encourage educators to think about their use in learning. Because of this, online education or e-learning or m-learning develops. More advanced is the growth of MOOCs (Massive Open Online Courses) which make knowledge accessible to many parties [3,4]. Along with this development, learning requires a learning management system that can meet the various needs of learning interactions. Teachers need simple LMS but sufficient learning needs.

The learning process can utilize some types of LMS such as Schoology, LearnBoost, Edmodo, Moodle, and others. Among others, Schoology is one of the websites that can combine social network and LMS; it is a social web that offers to learn as in the classroom for free $[5,6]$. One of LMS that has excellent and easy-to-use features and visualization is Schoology. Besides it is easy to use and open access for students involved in the learning process, Schoology also has various features that ease students to study, so it could encourage interest and increase student's learning achievement. 
Schoology is a website that combines e-learning and social network. Its concept is similar to Moodle, but e-learning with Schoology has many advantages and benefits compared to Moodle because it does not need hosting and the management is more user-friendly. Even though its features are not as complete as Moodle, it has been adequate for e-learning at school [7]. The advantage of Schoology is the attendance facility used to check student's attendance and analyze facility to observe all student's activities on each course, assignment, discussion and other exercises prepared for students [8]. Besides, to create more effective learning, it needs easy and efficient learning strategies, so it can liven up the situation in the classroom and encourage student's learning interest. Therefore, informal cooperative learning is suitable for that since it is a simple method with a lot of benefits. The importance of simple strategy in the learning practice is for the development of teacher's teaching technique daily, so it is more creative and more developed and grows broader learning process [9-12].

One of them is Think Pair and Share (TPS). Thus, it expects that with the strategy, students enjoy and engage in learning as learning will run effectively if students find it fun, comfortable and enjoyable [13,14]. Fun learning will appear if learning is meaningful for students $[15,16]$. Therefore, it seems that student's learning achievement is highly influenced by a series of specific lesson plans, which is coordinating fundamental components in learning $[17,18]$. However, the learning process also becomes less useful if in the learning process students are less involved, students tend to be more passive and only keep silent although they do not understand what their teacher is explaining. They just become passive listeners and do not want to give questions because they are less interested in learning. Whereas, the expectation is student's participation, so students actively participate in learning to achieve good learning process and achievement.

\section{Materials and Methods}

\subsection{Research Design}

This research is quasi-experimental research with pretest and posttest control group design. The objective of this research is to find out the influence of informal cooperative learning by using Schoology as a learning management system towards learning achievement viewed from the student's learning interest and numerical ability. This learning activity was applied in a public high school in Bima, West Nusa Tenggara. Through this research, researchers would find out whether the implementation of Think Pair and Share method using Schoology can improve student's learning interest and achievement in physics learning.

\subsection{Population and Sample}

The population covered five classes of eleventh-grade student. Randomly, we took two groups and assigned as control and experiment groups. Each group consists of 38 students. One teacher conducted informal cooperative learning using LMS at the experiment group (CL1). The other teacher implements the usual teaching method in the control group (CL2). Both groups used the same learning material as mandatory from Education Ministry of Republic Indonesia. We called BSE (Buku Sekolah Elektronik or e-book for school). See Fig. 1 for the textbook of Elasticity topic.

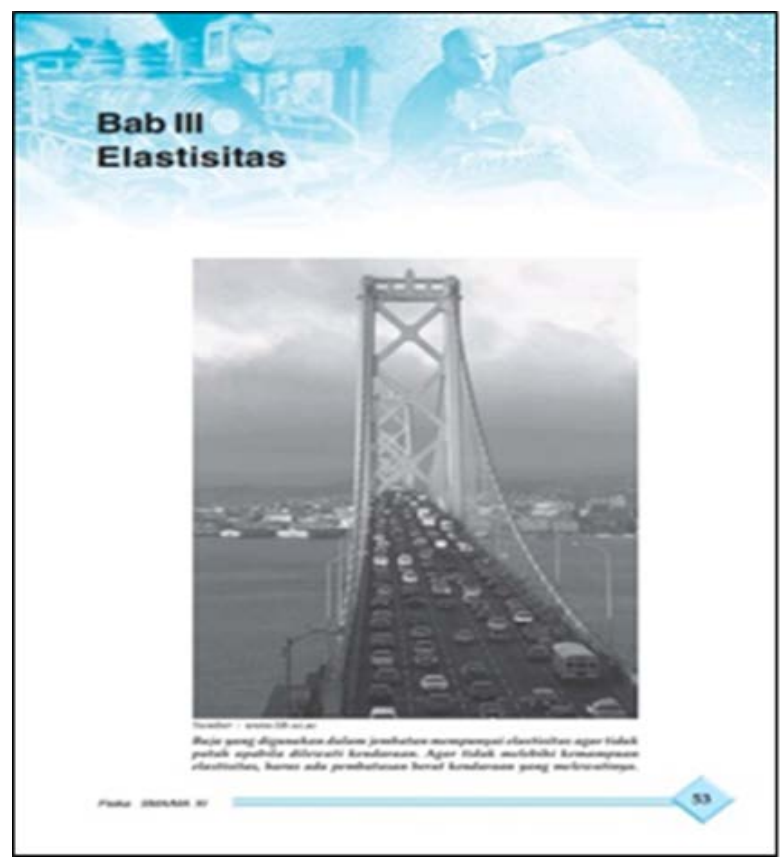

Figure 1. Chapter III: Elasticity (the textbook)

\subsection{Variables}

The independent variable is the physics learning strategy (IVAR). As mention before, the experiment group (CL1) taught using informal cooperative learning method supported by Schoology. The procedure of this strategy will describe in the next section. The dependent variable is the student's learning achievement (DVAR). DVAR was measured after all student had finished their learning activity for five sessions (90 minutes per session; 2 times per week).

As discussed in the introduction, student's learning interest (COV1) and numerical ability (COV2) are some factors influencing the learning achievement. We choose these variables to control this effect on the learning achievement measurement. 
5. Dalam suatu praktikum untuk menentukan konstanta suatu pegas diperoleh data sebagai berikut:

\begin{tabular}{|l|l|l|}
\hline No & $\mathrm{F}(\mathrm{N})$ & $\Delta \mathrm{x}(\mathrm{cm})$ \\
\hline 1 & 10 & 2,0 \\
\hline 2 & 15 & 3,0 \\
\hline 3 & 20 & 4,0 \\
\hline
\end{tabular}

Jika $\mathrm{F}$ adalah gaya dan $\Delta \mathrm{x}$ adalah pertambahan panjang pegas, maka konstanta pegas yang digunakan adalah?

\section{Translation:}

In the laboratory practicum for finding the spring constant, we found this data:

Table is here

If $\mathrm{F}$ is force and $\Delta \mathrm{x}$ is the extension of the spring, then calculate the spring constant.

Figure 2. The example of the problem.

\subsection{Instruments and Statistical Technique}

Prior knowledge (pretest) and learning achievement (posttest) were measured using the essay problems. These problems were arranged for higher order thinking skills of Bloom taxonomy. The number of problems is ten items. This problem has been analyzed related to the item validity, the difficulty index, the discrimination index.

We used the weighted score to find prior knowledge and learning achievement. The criteria are namely identification of the problem, interpretations of data or information, determination of strategy, application of the approach, and reflection or justification. The score of each is from 1 (below expectation) to 4 (exceed expectation). The example of the problem in Figure 2

One of the simple instrument to measure the learning interest is the ARCS model. We used this standard instrument to measure COV1. ARCS model consist of attention, relevance, confidence, and satisfaction factors representing the student interest. There are 34 statement items in this questionnaire which used Liker scale from 1 (SD: strongly disagree) to 5 (SA: strongly agree). Table 1 shows the structure of the questionnaire.

Table 1. The structure of the questionnaire

\begin{tabular}{|l|l|l|}
\hline \multirow{2}{*}{ Factors } & \multicolumn{2}{|l|}{ Item number } \\
\cline { 2 - 3 } & Positive statement & $\begin{array}{l}\text { Negative } \\
\text { statement }\end{array}$ \\
\hline Attention & $1,15,21,24,29$ & $4,10,26$ \\
\hline Relevance & $2,5,13,20,22,23,28$ & 8,25 \\
\hline Confidance & $3,6,11,27,30$ & 9,17 \\
\hline Statisfication & $7,12,14,16,18,19,32,33,34$ & 31 \\
\hline
\end{tabular}

We took the secondary data for the numerical ability of students. Every year, for every fresh student, will be tested in his/ her intelligent quotient (IQ) including the numerical ability. We used this data to represent COV2 in this study.

The teacher gave the test at the end of the learning activity to measure the students learning achievement (DVAR). This test consists of posttest by using self-ability analysis tested the student's learning achievement at the end of learning after all materials finished.

The primary technique of analysis was ANCOVA by using SPSS. The variables are independent variable (IVAR) consist of CL1 and CL2, dependent variable (DVAR), covariates consist of COV1 and COV2. The error margin was 0.05 . We used T-test for comparing the pretest mean to ensure that both groups had equality. Normality and homogeneity as a prerequisite before applying the ANCOVA. The linear regression technique was used to find out the covariate contribution to the dependent variable.

\subsection{Learning Mechanism}

The teacher used cooperative learning strategy with the think pair share (TPS) method. This method helps students to think individually about a topic or answer a question. In the first stage (Think), the teacher provides material in the LMS for students to read. Teachers need to create an exciting learning atmosphere by greeting them online. After that, the teacher directs students to study the material provided in the LMS.

In the second stage (Paired), the teacher encourages discussion. At this stage, the teacher must ensure that all students have studied the material. At this stage, problems can also be given to be resolved in groups.

In the third stage (Share), each group can convey the results of their work to students throughout the class and discuss the results with each other. Thus, this discussion teaches students to share ideas with classmates and build oral communication skills. This strategy also helps to focus attention and involve students in understanding reading material.

The learning object is video format, textbook, and link to OER (open educational resources). The teacher provides various forms so that students have a variety of alternative learning resources. Also, students can learn more from some examples of problems presented in LMS.

This stage of learning is carried out for other topics until it's finished. At the end of learning, the teacher gives a problem essay to be used as a measure of student learning outcomes.

In this learning activity, what is essential to be noticed by the teacher is to maintain intensive communication with students, providing feedback on each response made by 
students.

The main features used in this learning activity were Assignments and Events, Tests and Quizzes, and Discussions.

1. Assignments and Events allow the teacher to create a variety of different assignments that include content from a hard-drive or the web.

2. Tests and Quizzes allow instructors to create a variety of different types of questions for quizzes and test. These test and quizzes can include a wide range of media as well, making it easy to personalize and differentiate tests with ease.

3. Discussions allow the teachers to set up a threaded discussion which would enable for natural response and organizations. Posts can include a variety of files as well.

\section{Result}

\subsection{Learning Activity}

Schoology as the learning management system can be accessed via website https://app.Schoology.com/home or downloaded on Play Store. As mentioned in the method section, in the learning that has been carried out, the stages used are with informal cooperative learning type TPS.

\subsubsection{Think}

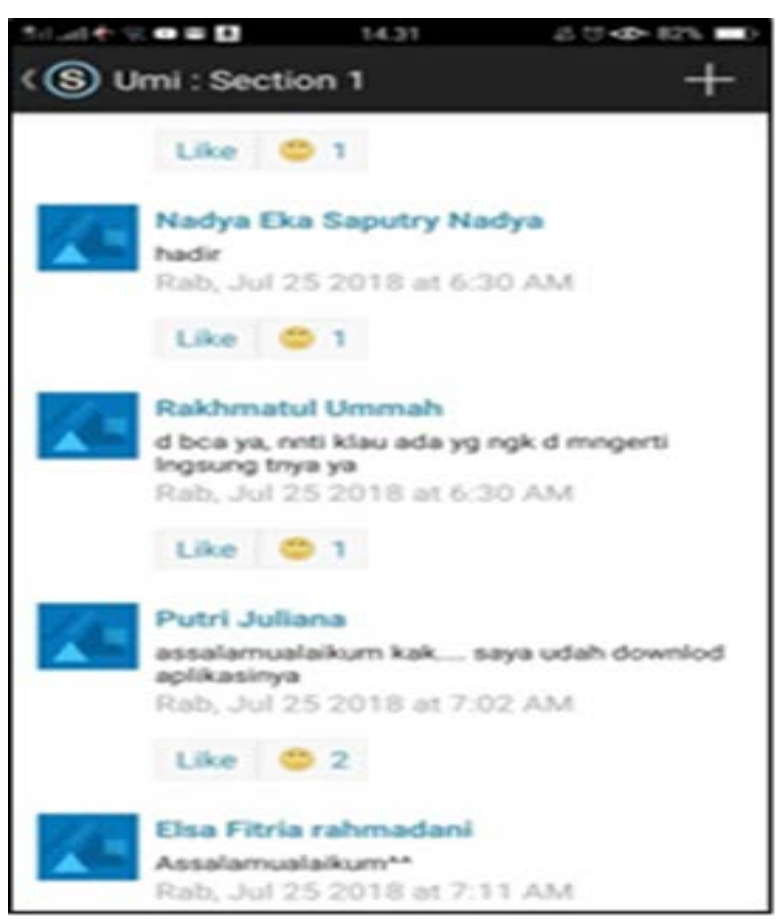

Figure 3. Greeting activities.

Before students individually do Think activities, the teacher ensures that students are present online. The teacher gives a greeting and also encourages fluid communication with students. Figure. 3 shows events at the beginning of learning.

In the next activity, the teacher provided teaching material uploaded to LMS. In this study, teaching material was taken from an electronic textbook. This book is a standard book from the Indonesian Ministry of Education. The cover screenshot of this book is as shown in Figure 1. Apart from the textbook, the teacher also provides other learning resources to enable students to have alternative learning resources. Figure 4 shows the screenshot in LMS related to learning resources.

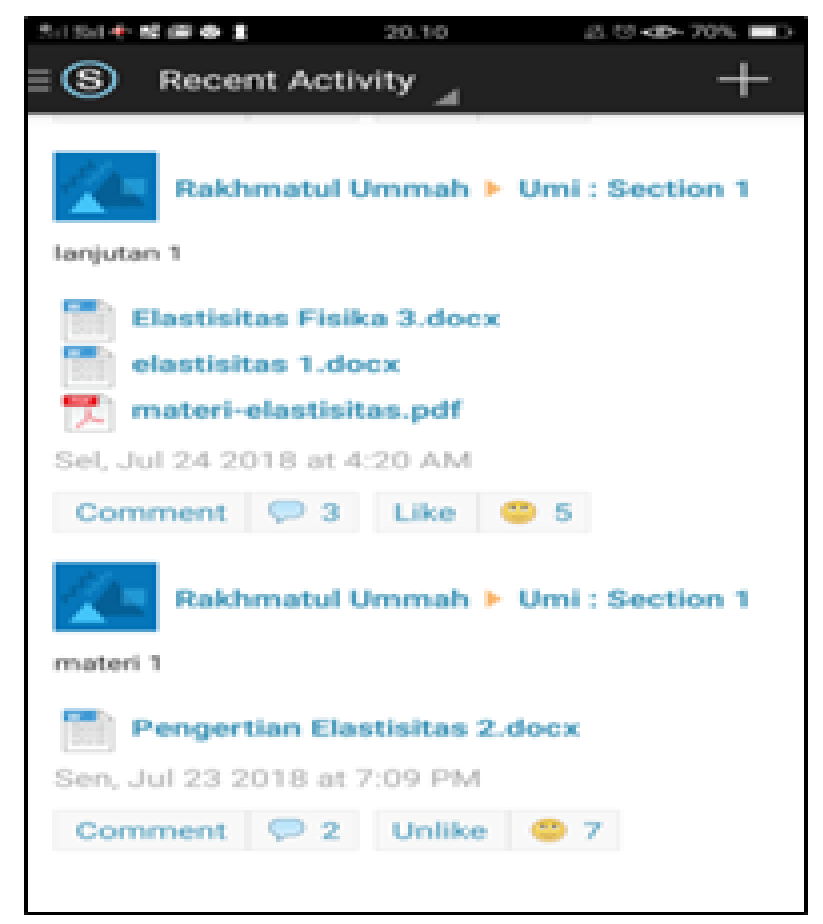

Figure 4. Teacher provided the learning material related to the Elasticity topic as the attachment on the LMS.

\subsubsection{Pair}

The teacher asked some concepts related to the material on the post to find out whether the students had read the content or not. This posting was done to ensure the readiness of students on discussion (Pair) to be done with a partner. After students studied the material independently, the teacher encouraged the implementation of discussion activities with a partner. In this activity, the teacher gave a problem that was done in pairs. Problems were related to the material and issues in daily life. The teacher provided an example problem to i mprove understanding. Figure 5 shows one of the problem examples. 


\title{
Contoh Soal 1
}

\author{
Setraah batang besi jarifiari $9 \mathrm{~mm}$ dan panjangnya $80 \mathrm{~cm}$. Batang ditarik \\ olch gaya sebecar $6 \times 10^{4} \mathrm{~N}$. (Tegangan patah besi $4 \times 10^{8} \mathrm{~N} / \mathrm{m}^{2}$ ) \\ 2. Derapakah teggangan tarik pada butang? \\ b. Berapakah perubahan panjang batang? Apolah besi patah? \\ Prnyrlesaian : \\ Diketabur : \\ Pançang bes $=L=80 \mathrm{~cm}=0,8 \mathrm{~m}$ \\ Leas penampung besi $=A=\pi r^{2}-3,14(9)^{2} m^{2}$ \\ larabl : \\ Teqangan tarik yang dialami besi: \\ $\frac{F}{A}=\frac{6 \times 10^{4} \mathrm{~N}}{(3,14)\left(9 \times 10^{3}\right) \mathrm{m}^{2}}=2,3 \times 10^{6} \mathrm{~N} / \mathrm{m}^{2}$ \\ Perubahan paniang beai \\ $\Delta L=\frac{(F / D) \mathcal{L}}{G}=\frac{\left(2,3 \times 10^{x} \mathrm{~N} / \mathrm{m}^{2}\right) 0,8 \mathrm{~m}}{2,0 \times 10^{11} \mathrm{~N} / \mathrm{m}^{2}}=9,2 \times 10^{-4} \mathrm{~m}$ \\ Besi bolum patah karena tegangan tarik besi masih di bawah togangan \\ patahnya.
}

Figure 5. The example of the Elasticity problem. This problem needs the numerical manipulation to solve it. At the first question (a), he/ she had to find the area first before calculated the tensile stress. At the second question (b), the student had to analyze before making a decision. Based on the Bloom taxonomy, this problem is in C4 analysis level.

We can see that from the problem, students learn high-level thinking skills. These skills are competencies that must be promoted in learning in Indonesian schools which stated in physics competencies.

\subsubsection{Share}

In the Share activity, all students discussed in posting; therefore, all student participated in the related solution of the problem. At this stage, the teacher encouraged students to communicate with other students actively. In this way, students develop their communication skills. If there are students who do not express their opinions, the teacher greets them to argue in the post.

The critical thing at this stage was the level of communication intensity in the posting. Teachers needed to immediately provide feedback on posts made by students, giving appreciation for the right student's comments, rectifying possible misconceptions.

\subsection{T-test}

T-test was conducted to find out whether there were significant differences between the mean of the pretest (prior knowledge) in the control group (CL2) and the experiment group (CL1). This test is carried out to ensure that the two groups have equality. Table 2 shows the test results.
Table 2. One-Sample Statistics

\begin{tabular}{|c|c|c|c|c|}
\hline & $\mathrm{N}$ & Mean & Std. Deviation & Std. Error Mean \\
\hline CL1 & 38 & 49.3421 & 10.27796 & 1.66731 \\
\hline CL2 & 38 & 45.1316 & 8.96591 & 1.45446 \\
\hline
\end{tabular}

From this T-test, it was found that at margin error 0.05 there was no significant difference in the two groups. Thus, the two groups have equality.

\subsection{Descriptive data}

After learning, students from both groups were given questions as many as ten problems. The results of the assessment of these problems were used as a learning achievement (DVAR) measure. Table 3 and Table 4 show the descriptive statistics of the measurement result of (DVAR), (COV1), and (COV2) respectively.

Table 3. Descriptive statistic of experiment group (CL1)

\begin{tabular}{|c|c|c|c|c|c|}
\hline & N & Min & Max & Mean & Std. Deviation \\
\hline $\begin{array}{c}\text { Learning } \\
\text { achievement (DVAR) }\end{array}$ & 8 & 60 & 90 & 75.9 & 6.629 \\
\hline $\begin{array}{c}\text { Learning Interest } \\
\text { (COV1) }\end{array}$ & 8 & 103 & 185 & 120.68 & 7.319 \\
\hline $\begin{array}{c}\text { Numerical ability } \\
\text { (COV2) }\end{array}$ & 8 & 94 & 124 & 105.89 & 7.255 \\
\hline
\end{tabular}


Table 4. Descriptive statistic of the control group (CL2)

\begin{tabular}{|c|c|c|c|c|c|}
\hline & $\mathbf{N}$ & Min & Max & Mean & Std. Deviation \\
\hline $\begin{array}{c}\text { Learning achievement } \\
\text { (DVAR) }\end{array}$ & 38 & 50 & 85 & 72.11 & 8.901 \\
\hline $\begin{array}{c}\text { Learning Interest } \\
\text { (COV1) }\end{array}$ & 38 & 103 & 131 & 125.34 & 10.816 \\
\hline $\begin{array}{c}\text { Numerical ability } \\
\text { (COV2) }\end{array}$ & 38 & 93 & 124 & 103.21 & 9.865 \\
\hline
\end{tabular}

In this data, T-test for COV1 and COV2 was also carried out to ensure that between the experimental group and the control group had equality. The results showed that the two covariates did not differ significantly for the two groups. It's just that the data shows that the standard deviation in the experimental group (CL1) is smaller than the control group (CL2) for both interset learning (COV1) and numerical abilities (COV2).

\subsection{Analysis of Prerequisite Test}

Reviews of prerequisite test used in this research were normality test and homogeneity test.

\subsubsection{Normality Test}

The normality test used Kolmogorov Smirnov test. From the normality test on the experiment group (CL1), the significance probability of the learning achievement (DVAR) was 0.101 . The significance probability of student's learning interest (COV1) was 0.101 and significance probability of numerical ability (COV2) was 0.118 . Since the significance probability of the three variables was higher than the significant level (0.05), then the three variables had a normal distribution. Meanwhile, from normality test on the control group (CL2), the significance probability of learning achievement (DVAR) was 0.116. The significance probability of student's learning interest (COV1) was 0.118, and the significance probability of numerical ability (COV2) was 0.345. It means that the three variables have a normal distribution.

\subsubsection{Homogeneity Test}

Based on the result of the homogeneity test using the Levene statistic calculation, the result showed that the three variables were homogenous. Seeing from the significant score of each variable that was higher than the significant level of 0.05, it meant that the experiment group (CL1) and control group (CL2) were homogenous.

\subsection{ANCOVA}

To find out whether there is an influence on student's learning achievement from posttest with student's numerical ability and learning interest here is the result of calculation by using ANCOVA as shown on the following Table 5.

Table 5. The result of ANCOVA: Tests of Between-Subjects effects

\begin{tabular}{|c|c|c|c|c|c|}
\hline Dependent Variable: Learning Achievement (DVAR) \\
\hline Source & Type III Sum of Square & Df & Mean Square & F & Sig. \\
\hline Corrected Model & $607.125^{\text {a }}$ & 3 & 202.375 & 3.462 & .021 \\
\hline Intercept & 195.165 & 1 & 195.165 & 3.339 & .072 \\
\hline Learning Interest & 57.590 & 1 & 57.590 & .985 & .324 \\
\hline Numerical Ability & 343.383 & 1 & 343.383 & 5.874 & .018 \\
\hline Groups & 210.916 & 1 & 210.916 & 3.608 & .061 \\
\hline Error & 4208.664 & 72 & 56.454 & & \\
\hline Total & 420400.000 & 76 & & & \\
\hline Corrected Total & 4815.789 & 75 & & & \\
\hline
\end{tabular}

a. $\mathrm{R}$ Squared $=.126$ (Adjusted R Squared $=.090$ )

Table 6. Coefficient of linear regression

\begin{tabular}{|c|c|c|c|c|c|c|}
\hline & \multirow{2}{*}{ Model } & \multicolumn{2}{|c|}{ Unstandardized Coefficients } & \multirow{2}{*}{$\begin{array}{c}\text { Standardized Coefficients } \\
\text { Beta }\end{array}$} & \multirow{2}{*}{$\mathrm{t}$} & \multirow{2}{*}{ Sig. } \\
\hline & & B & Std. Error & & & \\
\hline \multirow{3}{*}{1} & (Constant) & -117.536 & 36.916 & & -3.184 & .004 \\
\hline & COV1 & 1.847 & .319 & .734 & 5.784 & .000 \\
\hline & COV2 & -.119 & .120 & -.126 & -.993 & .329 \\
\hline
\end{tabular}




\subsection{Calculation of Contribution}

Predictor contributions (COV1 and COV2) can be seen in relative contributions and effective contributions. Linear regression analysis can be used to find out both types of contribution. The sum of the effective contributions of these two covariates is the same as the $\mathrm{R}$ square value or the coefficient of determination. The relative contribution is the magnitude of predictor contribution to the square of regression. Table 6 shows the result of the linear regression analysis for the experimental group.

Table 7 shows the correlation coefficients of each variable to others. We used this table for calculate the contribution of the variates to the dependent variable.

Table 7. The correlation coefficient

\begin{tabular}{|c|c|c|c|c|}
\hline \multicolumn{2}{|c|}{} & DVAR & COV1 & COV2 \\
\hline \multirow{3}{*}{ DVAR } & Pearson Correlation & 1 & .212 & .089 \\
\cline { 2 - 5 } & Sig. (2-tailed) & & .001 & .596 \\
\cline { 2 - 5 } & $\mathrm{N}$ & 38 & 38 & 38 \\
\hline \multirow{3}{*}{ COV1 } & Pearson Correlation & .012 & 1 & .397 \\
\cline { 2 - 5 } & Sig. (2-tailed) & .201 & & .035 \\
\cline { 2 - 5 } & $\mathrm{N}$ & 38 & 38 & 38 \\
\hline \multirow{3}{*}{ COV2 } & Pearson Correlation & .489 & .197 & 1 \\
\cline { 2 - 5 } & Sig. (2-tailed) & .045 & .035 & \\
\cline { 2 - 5 } & $\mathrm{N}$ & 38 & 38 & 38 \\
\hline
\end{tabular}

Table 8 describes that COV2 has higher correlation to DVAR than COV1. The linear regression analysis is needed to find out the contribution of both variates to the DVAR. The model summary of this case was used to calculate the COV1 and COV2 contribution. The number of R-square was .6788. This value was used to calculate the relative contribution of the independent variable to the dependent variable. The final calculation of the contribution is in Table 8.

Table 8. Contribution of covariates

\begin{tabular}{|c|c|c|}
\hline Variable & Effective Contribution & Relative Contribution \\
\hline COV1 & 34.62 & 51.0 \\
\hline COV2 & 32.27 & 49.0 \\
\hline
\end{tabular}

The percentage of effective contribution of experiment group from learning interest towards learning achievement was $34.62 \%$ and from numerical ability towards one was $32.27 \%$. The relative contribution of experiment group from learning interest toward learning achievement was 51\% and from numerical ability toward one was $49 \%$.

\section{Discussion}

\subsection{The Influence of Student's Learning Interest towards Learning Achievement}

The result of this research shows that the analysis of covariant and double linear calculated based on each construct from ARCS interest questionnaires used to measure the influence of student's learning interest towards learning achievement shows that the higher student's learning interest will influence student's learning achievement, vice versa. The lower student's learning interest, the lower learning achievement [17]. Students, who get a small achievement, usually do not like the learning materials or the way teacher explains in the class is not exciting and fun, so they tend to avoid studying at home or listening carefully to the teacher in the class.

On the calculation result of control and experimental classes, it appears the similar result which is student's learning interest influences the learning achievement, even though there is a difference in the outcome because learning interest and achievement of the experiment group is higher than the average compared to the result of the control group. This result could appear because of the different treatment given to the two groups. The experiment group used informal cooperative learning with Think Pair Share by using Schoology application, while the control group used a lecture or conventional learning method.

Think pair share is a simple learning method with a lot of benefits. One of them is students can more participate and blend in the class, work in a group, discuss, and share what they understand to other friends in the class [21]. Schoology is an application that is easy to be used by students with various features that could ease students in learning, interact with the teacher and other friends, students are easy to get materials taught by the teacher [8].

\subsection{The influence of Student's Numerical Ability towards Learning Achievement}

The result of this research shows that analysis of covariates calculated to measure the impact of student's numerical ability towards learning achievement demonstrates that the measurement of the influence of student's capability towards student's learning achievement was positive. The numerical ability of each group measured in this research has no significant difference, but seeing from the average of each group, the mean of the numerical ability of experiment group was little bit higher than the control group. It appears that numerical ability has influences in learning achievement. Students who have the good numerical ability get higher learning achievement; students who have low numerical ability have lower learning achievement because the numerical ability is the ability to calculate and process numbers. Physics always relates to concept understanding and counting; if students have no excellent concept understanding and good counting ability, it's hard to get proper learning achievement. As an opinion said that students who are smart in counting tend to have a passion for finishing every question given to them, while students 
who are the lack in counting tend to be lazy in doing problems and often depend on their friends. Therefore, an excellent numerical ability is necessary for doing and understanding questions to improve learning achievement [19].

\subsection{The Significant Influence of Learning Achievement between Experimental and Control Class}

In this research, learning achievement data from the posttest of experimental and control classes have differences. The average score of the experiment group is higher than control class because the higher score of student's learning interest of experiment group compared to control group and the different treatment towards the two groups; experiment group used think pair share by using Schoology application while the control group used a lecture or conventional method. Besides, the high and low student's interest is also influenced by the high and low of student's numerical ability. It means learning strategy, learning interest, numerical ability, and learning achievement have a relationship. A good learning strategy is a strategy that makes students comfortable, enjoyable and fun during learning $[13,14]$. From liking and enjoying learning, student's interest to study can grow. Besides, learning interest can also improve if students have an excellent numerical ability so that students will be more enthusiastic in learning [20]. Thus, the student's learning achievement will highly increase. From the explanation, it seems that there is a significant difference between the learning achievement of the experimental and control class.

\subsection{Effective and Relative Contribution of Learning Interest and Numerical Ability towards Learning Achievement}

The implementation of informal cooperative learning that supported by Schoology gave the positive impact on the learning achievement. The learning interest gave the effective contribution of $34.64 \%$ and the relative contribution of $51 \%$ towards learning achievement. While, numerical ability gave the effective contribution of $33.27 \%$ and the relative contribution of $49 \%$ towards learning achievement. The rest contribution (32.1\%) of the effective contribution of learning interest and numerical ability towards learning achievement is influenced by other factors which are not measured. The higher number of the effective and relative contribution of learning interest implies that students accept the informal cooperative learning strategy using Schoology. Therefore, it is a recommendation for teachers to implement this learning strategy as one of the strategy to give optimal influence on learning achievement $[19,20,22]$.

\subsection{The Research Influence on Learning}

This research used Schoology as teaching aid with think pair share informal cooperative learning strategy to support the learning process. By using Schoology, the teacher and students experienced a lot of ease in the learning process such as [8]

1. The teacher could post online assignment and evaluation for the class.

2. Students could check or download assignment documents,

3. Students then could submit assignments via Schoology course dropbox,

4. The teacher could evaluate with comments and or annotation on student's works and give them back to students to be reviewed.

Besides, teachers could also make a code for parents to follow the course and observe their children's progress. It makes Schoology exciting and easy for them to navigate and study. Besides, almost all teachers could register for accounts, develop courses, collect resources, join one or more groups, and start to post online course materials in the first hour of professional development training. Students could also access class materials anywhere and anytime [7].

\section{Conclusions}

This study concluded that Schoology, as an online teaching aid, combined informal cooperative learning strategies can encourage the achievement of student learning performance. This result also showed that the integration of ICT in teaching could facilitate the process of sharing, exchanging, and maintaining active online classrooms. In further research, it is necessary to study the application of this strategy to different disciplines and to apply it to the more significant students and classes. Therefore, the impact of its utilization is more visible.

\section{Acknowledgements}

This research is funded by the Ministry of Research, Technology and Higher Education through Postgraduate Research Grant Scheme, the Year 2019.

\section{REFERENCES}

[1] H. Crompton, D. Burke, K. H. Gregory, C. Gräbe C (2016). The use of mobile learning in science: A systematic review, Journal of Science Education and Technology, Vol. 25, No. 2, 149-160, 2016.

[2] W. H. Wu, Y. C. J. Wu, C. Y. Chen, H. Y. Kao, C. H. Lin, S. $\mathrm{H}$. Huang. Review of trends from mobile learning studies: A meta-analysis, Computers \& Education, Vol. 59, No. 2, 817-827, 2012. 
[3] J. Kay, P. Reimann, E. Diebold, B. Kummerfeld. MOOCs: So many learners, so much potential... IEEE Intelligent systems, Vol. 28, No. 3, 70-77, 2013.

[4] T. R. Liyanagunawardena, A. A. Adams, S. A. Williams. MOOCs: A systematic study of the published literature 2008-2012, The International Review of Research in Open and Distributed Learning, 14(3), 202-227, 2013.

[5] S. Biswas. Schoology-supported classroom management: A curriculum review, Northwest Journal of Teacher Education, Vol. 11, No. 2, 187-196, 2013.

[6] F. Khaddage, W. Müller, K. Flintoff. Advancing mobile learning in formal and informal settings via mobile app technology: Where to from here, and how? Journal of Educational Technology \& Society, Vol. 19, No. 3, 16-26, 2016.

[7] H. Crompton, D. Burke, K. H. Gregory. The use of mobile learning in PK-12 education: A systematic review, Computers \& Education, Vol. 110, 51-63, 2017.

[8] A. Krouska, C. Troussas, M. Virvou. Comparing LMS and CMS platforms supporting social e-learning in higher education, In 8th International Conference on Information, Intelligence, Systems \& Applications (IISA) (pp. 1-6), IEEE, 2017.

[9] J. Cunningham, E. Hillier. Informal learning in the workplace: key activities and processes, Education and Training, Vol. 55, 312-332, 2013.

[10] D. Sulisworo, S. P. Agustin, E. Sudarmiyati. Cooperative-blended learning using Moodle as an open source learning platform, International Journal of Technology Enhanced Learning, Vol. 8, No. 2, 187-198, 2016.

[11] C. Greenhow, C. Lewin. Social media and education: Reconceptualizing the boundaries of formal and informal learning, Learning, media and technology, Vol. 41, No. 1, 6-30, 2016.

[12] I. Grosemans, A. Boon, C. Verclairen, F. Dochy, E. Kyndt. Informal learning of primary school teachers: Considering the role of teaching experience and school culture, Teaching and Teacher Education, Vol. 47, 151-161, 2015.

[13] B. Czerkawski. Blending formal and informal learning networks for online learning, the international review of research in open and distributed learning, Vol. 17, No. 3, 138-155, 2016.

[14] F. Mohammadjani, F. Tonkaboni. A Comparison between the Effect of Cooperative Learning Teaching Method and Lecture Teaching Method on Students' Learning and Satisfaction Level, International Education Studies, Vol. 8, No. 9, 107-112, 2015.

[15] C. Lange, J. Costley, S. L. Han. Informal cooperative learning in small groups: The effect of scaffolding on participation, Issues in Educational Research, Vol. 26, No. 2, 260-279, 2016

[16] N. L. Ennen, E. Stark, A. Lassiter. The importance of trust for satisfaction, motivation, and academic performance in student learning groups, Social Psychology of education, Vol. 18, No. 3, 615-633, 2015.

[17] V. Collinson. Learning to share, sharing to learn: Fostering organizational learning through teachers' dissemination of knowledge, Journal of Educational Administration, Vol. 42, No. 3, 312-332, 2004.

[18] R. E. Slavin. When does cooperative learning increase student achievement? Psychological bulletin, Vol. 94, No. 3, 429, 1983.

[19] R. S. Siegler, D. W. Braithwaite. Numerical development, Annual Review of Psychology, Vol. 68, 187-213, 2017.

[20] Y. J. Lee, C. H. Chao, C. Y. Chen. The influences of interest in learning and learning hours on learning outcomes of vocational college students in Taiwan: using a teacher's instructional attitude as the moderator. Global journal of engineering education, Vol. 13, No. 3, 140-153, 2011.

[21] H. Heflin, J. Shewmaker, J. Nguyen. Impact of mobile technology on student attitudes, engagement, and learning, Computers \& Education, Vol. 107, 91-99, 2017.

[22] D. W. Johnson DW, R. T. Johnson. Making cooperative learning work. Theory into practice, Vol. 38, No. 2, 67-7, 1999. 